\title{
DEBT CONTRACTS AND CAPITAL STRUCTURE ADJUSTMENT SPEED IN THE TEHRAN STOCK EXCHANGE
}

\author{
Zahra Farhadi $^{1}$, Narjes Kamali Kermani ${ }^{2}$, Abdolhossein Talebi Najafabadi ${ }^{3 *}$, Mohammad Vahdani ${ }^{4}$ \\ ${ }^{1,3,4}$ Assistant Prof., Accounting, Faculty of Humanity Sciences, University of Bojnord, Bojnord, Iran \\ ${ }^{2}$ Instructor, Accounting, Faculty of Humanity Sciences, University of Bojnord, Bojnord, Iran \\ 12.farhadi@ub.ac.ir, ${ }^{2}$ n.kamali@ub.ac.ir, ${ }^{3 *}$ ab.talebi@ub.ac.ir, ${ }^{4}$ m_vahdani99@yahoo.com
}

Article History: Received on $02^{\text {nd }}$ February Revised on $30^{\text {th }}$ April, Published on $20^{\text {th }}$ July 2019

\begin{abstract}
Purpose of the Study: A competitive market and the complexity of the business environment led to the special attention of practitioners in the field of economics to the capital structure and, especially, economic units of debts. The current study investigates the relationship between debt contracts and changes in the capital structure of 114 companies listed on the Tehran Stock Exchange from 2011 to 2016.

Methodology: In this research, the data was extracted, classified, and calculated by using Excel software and ultimately, the hypotheses were tested at a 95\% confidence level through E-views and Stata software.

Conclusions / Results: The results indicate that there is no significant relationship among debt contracts, debt contract restrictions, and debt contract in the unfavorable financial conditions with the capital structure adjustment speed in the companies listed on the Tehran Stock Exchange in the studied time interval, but this relationship is visible between two variables of debt contracts and capital structure adjustment speed in the companies that have a high financial leverage.

Novelty: The study of financing of leveraging methods is very important in considering different factors. That is, choosing any cheap or expensive debt on the part of the company, while changing the cost of capital, will create favorable profit opportunities or lead to a critical situation. Accordingly, the present research in the subject area, time, and place of interest can overcome the doubts of stakeholders in the mindset of companies.
\end{abstract}

Keywords: Debt Contracts, Debt Contracts Restrictions, Financial Leverage, Capital Structure

\section{INTRODUCTION}

Regarding the business development, financing methods are very important, as lead to maintain and expand the market in the current complex competitions. This financing can be done through two short-term and long-term dimensions. Anyway, the aim of all companies is to maintain and increase return on equity; therefore, such methods are used to achieve this important goal. Increase in returns on equity leads to a decrease in the cost of capital and, in fact, increases the value of the company. In other words, investors and creditors act as two effective factors on the capital structure of the companies by granting their capital or money to the company, accept non-receipt of payment, and obtain returns equivalent to the cost of capital imposed on the company. When we are talking about capital structure, a suitable financial leverage will be a suitable and important measure for the capital structure, because it can have a significant impact on the existing competitive advantages in such a way that higher financial leverage leads to higher competitive ability (Setayesh \& Jamaliyan Pour, 2011). Of course, several factors have led companies to take caution when they provide their desired funds. Some of these factors are company size, status of managers, rate of production and sales, sources of obtaining raw materials, access to financial markets, and the economic and political environments. These factors have also made them cautious about making optimal decisions (Sinyai, 2007). Anyway, financing through debt, due to tax savings and the rate being lower than the expected returns of the shareholders, has led managers to opt for this kind of financing. Consequently, this research was designed to investigate the relationship between debt contracts and capital structure adjustment speed and has achieved satisfactory results after completing the research stages.

Regarding different factors, investigating the financing procedure through financial leverage is really important. It means that choosing any cheap or expensive debt by the company, while changing the cost of the asset, leads to the creation of suitable profitability opportunities or critical conditions (De Angelo \& Masuli, 1980). Due to this fact, this research in the related subject, time, and place realm can resolve the doubts in line with the thought of the companies' beneficiaries.

In the unrestrained and complex business world that has been accompanied by rapid technological changes, the expansion of capital markets has raised the importance of capital supply and stakeholder interests. Creditors can be considered as beneficiaries in companies among those groups. This group has asymmetric returns in relation to the net 
asset; when the net asset value is higher than the debt nominal value, regardless of how much this added value is, debt holders will not receive any additional remuneration.

On the other hand, the role of company financial structure in the production market behavior is an important topic for financial economists. In an ideal economic world, the whole value of the securities market of the company is determined by the power of profitability and the risk of their related assets and it should be independent of the securities combination (i.e., debt and equity). The current working environment of companies is developing and competitive and companies are obliged to compete with several factors at national and international levels and develop their activities through brandnew investments for surviving. Capital structure is the most important factor, which is effective on the valuation and orientation of companies in the capital market (Pourheidari, 1995). It is assumed that debts and shareholders' rights indicate financial sources that companies used to get assets. Often, financing by means of debts due to tax saving and its lower rate compared with shareholders' expected return, is very important for managers; therefore, managers probably manifest the suitable condition of the company's profitability to attract creditors and obtain enough investment and reduce debt cost. Accordingly, the present paper aims to find a suitable answer for the following question by means of a systematic procedure.

\section{Are debt contracts effective on the capital structure of the companies listed on the Tehran Stock Exchange?} REVIEW OF RELATED LITERATURE

The optimal capital structure is a structure in which the capital cost has been minimized. Since the late 1950s, efforts have been made to find an optimal capital structure but no specific model has been presented for it. Capital cost is a cognitive concept, despite different formulas to calculate this concept, and it cannot be claimed that capital cost is a specific figure. This research investigates one of the factors affecting the capital structure and talks about the theoretical foundations in domestic and foreign researches, which are very important.

Debts and rights of shareholders indicate financial resources used by companies to obtain assets. If a company supplies a part of its capital through a loan (debt), its shareholders will accept more risks and may also gain a greater return. If a company, by means of investment, gets a higher return compared with an interest rate of the acquired loan, the profit of each share of the company will increase. On the one hand, an important factor for creditors in line with loans and credits is the ability to pay interest on loans and paid credits.

Mostly, financing through debts is very important for the manager of the companies due to the tax savings and its lower rate compared with the shareholders' expected return. But the key issue for creditors, in line with loan and credit, is the ability of the repayment of loans and credits. In western countries, such as the U.S., creditors pay attention to the company's financial statements to assess the ability to repay the loan and its interest. Debt contract is really important in such cases. Of course with regard to the importance of financial statements, especially decision making in the income statement in line with loans and credits, the manager may manifest the suitable conditions of the company to attract creditors and obtain the necessary investment, and decrease debts. This raises the concerns of the stakeholders.

In the agency theory, it is indicated that company owners and shareholders delegate their authority to managers to make necessary decisions, but managers have personal goals that are not consistent with the shareholders' ideas in line with wealth maximization. Thus, it can be indicated that the agency theory can create a conflict of interest. Based on the Modigliani-Miller theorem, capital structure has no effect on the company value, but is based on the agency theory. Even if the assumptions of the Modigliani-Miller theorem are correct from the point of view of corporate governance, an appropriate combination of debt and equity is important (former source). The current research has been planned on the basis of the thought that debt contracts can have tangible effects on the capital structures and adjustments.

Erik Devos et al. (2017) in a study entitled "Debt contracts and the speed of capital structure adjustment" achieved findings that were not consistent with the results of the current study. The reason for this can be due to the cultural, religious, economic, and temporal differences. Ramesheh et al. (2017) in their research investigated the capital structure consistency in the Tehran Stock Exchange. They assessed three main patterns by means of simulation methods. In this research, the measure of choosing the best pattern was the ability in line with producing actual stable leverage. The results of the study indicated that there was instability in the capital structure in the interested time interval. Also, a set of patterns that related to the optimal leverage are defined as a valid set to describe the behaviors of leverage.

Gorji and Raie (2015) investigated the capital structure adjustment speed emphasizing the factor of the product's market competition. The results of the study showed that companies are moving rapidly towards the ratio of the target debt. Hashemi and Keshavarzmehr (2015) investigated the effect of several company variables on the cost of structural 
adjustment and these variables are financial imbalances, growth opportunities, investment, profitability, firm size, and income volatility. The results indicated that companies are moving at a high speed towards the optimal financial leverage. The results also manifested that those companies with fiscal deficit and profitability and lower income fluctuations have a higher speed of adjustment than companies with the opposite characteristics.

Sunder, Sunder, and Zhang (2009) investigated the effect of conservatism on debt contracts. The results of their study indicated that there is a direct relation between conservatism and debt level. Zhang (2008) investigated the benefits of conservative accounting for debt contract parties. His findings indicate that in case of using conservative accounting (conditions in a debt contract), if the credit recipients violate these conditions, creditors will benefit from premature maturity and penalties imposed by creditors. On the other hand, creditors also demand a lower interest rate than companies using conservative accounting and debtors also benefit from lower interest rates, is due to reduced agency costs of debt.

Akhtar (2005) investigated the effective factors in determining the capital structure of multinational corporations in Australia. The results indicate that in all of these companies, growth opportunities and company size are the factors that determine the ratio of debt. Pandey (2004) investigated the relationship among capital structure and profitability and market structure in Malaysia. The results indicated a non-linear relationship between capital structure and market structure. Also, by means of implementing the generalized method of moments (GMM), their hypothesis was approved on the basis of the cubic form of relationship between capital structure and market structure and the relationship between the structure of capital and profitability.

Rathinasamy et al. (2000) investigated the relationship between capital structure and market structure in 49 countries and a positive and significant relationship was observed. Brander and Lewis (1986) investigated the relationship between capital structure and market structure. Finally, their research presented a framework for this topic and led to confirmation of this fact due to the mediator variable of competitive behavior.

\section{RESEARCH OBJECTIVE, HYPOTHESES AND MODELS}

The main aim of this research is to investigate the relationship between debt contract and the speed of capital structure adjustment in companies in which their stocks have been presented in the exchange market, which has been less considered in previous studies.

Another objective of this study is to pay attention to these companies due to the cost-effectiveness and operational efficiency that are present for the investors. As mentioned before, the investigation of the conducted researches in different countries manifest the relationship in the mentioned field. The present study, while presenting new evidence from a different environment of Iran, will be considered as a small step towards explaining the scientific findings of previous researchers and enrich the literature of this field at the international level. On the other hand, all stakeholders will be notified and assured about their investments. In other words, the beneficiaries, based on the findings of this research, will be able to confidently make decisions about the type of investments.

Since the debt contracts are considered as one of the important sources of demand for capital structure, the hypotheses below will be mentioned about these variables:

H1: Debt contracts have a relationship with capital structure adjustment speed.

H2: Debt contract constraints have a relationship with capital structure adjustment speed.

H3: The relationship between debt contract constraints and capital structure adjustment speed is more robust in companies that do not have a good financial position.

H4: The relationship between debt contract constraints and capital structure adjustment speed is more robust in companies that have more powerful financial leverage.

The following model is used to examine the first research hypothesis.

Model (1):

$\triangle$ LEV $_{\text {it }+1}=\beta_{0}+\beta_{1}$ LEVDEV $_{\text {it }}+\beta_{2}$ COVDUMMY $_{\text {it }}+\beta_{3}$ LEVDEV $^{*}$ COVDUMMY $_{\text {it }}+\varepsilon_{i t}$

$\triangle \mathrm{LEV}_{\mathrm{it}+1}=$ financial leverage which has been calculated as follows: 
$T L E V=\frac{D}{D+S * P}$

$\mathrm{D}=$ Book value of company shareholders' equity, $\mathrm{S}=$ The number of company shares and $\mathrm{P}=$ Price per share at the end of the year

$\mathrm{LEVDEV}_{\mathrm{it}}=$ The difference between the optimal financial leverage and the financial leverage of the company

COVDUMMY $_{\text {it }}=$ If the company faces a limitation on financing, 1 otherwise it is zero.

Instead of the existence or absence of a limitation on debt, the number of existing restrictions has been taken into account in the second hypothesis to examine the model being used by it.

Model (2):

$\triangle$ TLEV $_{\text {it }+1}=\beta_{0}+\beta_{1}$ LEVDEV $_{i t}+\beta_{2} \operatorname{COVINST}_{i t}+\beta_{3}$ LEVDEV $^{*} \operatorname{COVINST}_{\text {it }}+\varepsilon_{\text {it }}$

In the third hypothesis, the moderator variable of free cash flow is used. This variable is as follows:

$\mathrm{FCF}=$ Free cash flow - tax and capital costs

Consequently, the model used to examine this hypothesis is as follows:

Model (3):

$$
\begin{aligned}
\triangle \text { TLEV }_{\text {it }+1}= & \beta_{0}+\beta_{1} \text { LEVDEV }_{\text {it }}+\beta_{2} \text { COVDUMMY }_{\text {it }} \\
& +\beta_{3} \text { LEVDEV } \text { COVDUMMY }_{\text {it }}+\beta_{4} \text { FCF }_{i t}+\beta_{5} \text { FCF } * \text { LEV }_{\text {it }}+\varepsilon_{\text {it }}
\end{aligned}
$$

Finally, the following model is used to test the fourth hypothesis;

Model (4):

$$
\begin{aligned}
\triangle \text { TLEV }_{\mathrm{it}+1}= & \beta_{0}+\beta_{1} \text { LEVDEV }_{\mathrm{it}}+\beta_{2} \text { COVDUMMY }_{\mathrm{it}} \\
& +\beta_{3} \text { LEVDEV } \text { COVDUMMY }_{\mathrm{it}}+\beta_{4} \text { OVERLEV }_{\mathrm{it}}+\beta_{5} L E V D E V * \text { OVERLEV }_{\mathrm{it}} \\
& +\beta_{6} \text { COVDUMMY } \text { OVERLEV }_{\mathrm{it}}+\beta_{7} \text { LEVDEV } * \text { OVERLEV } * \text { COVDUMMY } \\
& +\varepsilon_{\mathrm{it}}
\end{aligned}
$$

In these models:

OVERLEV $_{\text {it }}=$ Too much financial leverage and if the optimal financial leverage is greater than the actual financial leverage 1, then it is zero. These models have been used by Devos et al. (2017) and their efficiency has been proven to examine the hypotheses of this research.

\section{RESEARCH METHODOLOGY}

This research is based on its objective and is applied on the basis of nature and method. It is correlational since the data used in this study are actual and based on historical information and it can be classified as ex-post facto research. With regard to the research method, E-views statistical software was used for studying the collected data to test the hypotheses of the research, descriptive statistics, linear regression analysis, and related tests.

With regard to the aim of the study and the definition of research variables, the statistical population of this research is composed of all companies whose shares are presented in the Tehran Stock Exchange during the period from 2011 to 2016.

The statistical population of this research has been limited on the basis of three measures presented below:

1. Considering the time interval of the current research (2011-2016), the name of the company should be on the list of stock market exchange list.

2. After the first public offering, buying and selling their stock should not be stopped for a long time.

3. Documents, records, and reports required must be available for model testing.

Finally, 114 companies were surveyed after using the above criteria. 


\section{ANALYSIS AND INTERPRETATION OF THE DATA}

A series of assumptions are made to investigate the hypotheses by means of the mentioned regression models, which will be discussed later.

\section{Determining the Method of Using Pooling Data}

In order to determine the method of using the pooling method in contrast to the panel method, the F Limier test has been used. The significance level of the test was used. If the significance level is less than 0.05 , then the panel method would be used, and if the significance level is more than 0.05 , then the pooling method would be used. According to the carried out tests and based on the significance level, the panel method was used for the first, third, and fourth models, and the pooling method was used for the second model.

Table 1: $\mathrm{F}$ (Limier) test results to choose a pooling or panel method

\begin{tabular}{llrrl}
\hline Model & Zero hypothesis (H0) & $\mathrm{F}$ & $\mathrm{p}$-value & Test Result \\
\hline 1st model & The pooling method is appropriate & 114.103 & 0.000 & $\begin{array}{l}\text { H0 is not confirmed } \\
\text { (The panel data method is selected) }\end{array}$ \\
2nd model & The pooling method is appropriate & 9.116 & 0.198 & $\begin{array}{l}\text { H0 is confirmed } \\
\text { (The pooling method is selected) }\end{array}$ \\
3rd model & The pooling method is appropriate & 114.103 & 0.000 & $\begin{array}{l}\text { H0 is not confirmed } \\
\text { (The panel data method is selected) }\end{array}$ \\
4th model & The pooling method is appropriate & 114.103 & 0.000 & $\begin{array}{l}\text { H0 is not confirmed } \\
\text { (The panel data method is selected) }\end{array}$ \\
\hline
\end{tabular}

Given the use of panel data confirmation in the first, third, and fourth models, the Hausman test was used to determine the type of fixed or random effects in Table 2.

Table 2: Hausman test results

\begin{tabular}{lllll}
\hline Model & Zero hypothesis (H0) & Chi-square statistics & $\mathrm{p}$-value & Test result \\
\hline 1st model & Using random effects method & 11.999 & 0.000 & $\begin{array}{l}\text { H0 is not confirmed } \\
\text { (Fixed effects method is selected) }\end{array}$ \\
3rd model & Using random effects method & 41.003 & 0.000 & (Fixed effects method is selected) \\
4th model & Using random effects method & 41.001 & 0.000 & (Fixed effects method is selected) \\
\hline
\end{tabular}

Investigating the Classical Linear Regression Assumptions

\section{Breusch-Pagan Test}

In order to investigate the homogeneity of variance, the Breusch-Pagan test was used in this study. The results of this test are presented in Table 3.

Table 3: Breusch-Pagan test results

\begin{tabular}{|c|c|c|c|c|}
\hline Model & Zero hypothesis (H0) & $\begin{array}{l}\chi^{2} \\
\text { statistics }\end{array}$ & $\mathrm{p}$-value & Test Result \\
\hline 1st model & Homogeneity of variances & 0.3487 & 0.7984 & $\begin{array}{l}\mathrm{H} 0 \text { is not rejected } \\
\text { (There is no heterogeneity of variance) }\end{array}$ \\
\hline 2nd model & Homogeneity of variances & 0.5864 & 0.5972 & $\begin{array}{l}\mathrm{H} 0 \text { is not rejected } \\
\text { (There is no heterogeneity of variance) }\end{array}$ \\
\hline 3rd model & Homogeneity of variances & 1.3921 & 0.2451 & $\begin{array}{l}\mathrm{H} 0 \text { is not rejected } \\
\text { (There is no heterogeneity of variance) }\end{array}$ \\
\hline 4th model & Homogeneity of variances & 2.988 & 0.008 & $\begin{array}{l}\mathrm{H} 0 \text { is rejected } \\
\text { (There is heterogeneity of variance) }\end{array}$ \\
\hline
\end{tabular}

Taking into account the results of Table 3, since the test statistics is less than $0.05(0.000)$ it can be concluded that in the fourth relation of the research, there is heterogeneity of variance. But this problem was not observed in the first to third models.

\section{Breusch-Godfrey Test}

The Breusch-Godfrey test was used to investigate the presence of autocorrelations. The information of this test analysis is presented in Table 4. 
Table 4: Breusch-Godfrey test results

\begin{tabular}{llrrl}
\hline Model & Zero hypothesis (H0) & $\chi^{2}$ statistics & p-value & Test Result \\
\hline 1st model & There is no autocorrelation & 2.118 & 0.000 & H0 is rejected (There is autocorrelation) \\
2nd model & There is no autocorrelation & 2.118 & 0.000 & H0 is rejected (There is autocorrelation) \\
3rd model & There is no autocorrelation & 2.118 & 0.000 & H0 is rejected (There is autocorrelation) \\
4th model & There is no autocorrelation & 2.118 & 0.000 & H0 is rejected (There is autocorrelation) \\
\hline
\end{tabular}

Considering the results of Table 4 , since the test statistics are less than 0.05 (0.000), it can be concluded that there is serial correlation in the first to fourth correlations and the generalized least squares method should be used to analyze the information.

\section{Hypothesis-wise Results}

The research study revealed the following results:

\section{Test results of the first hypothesis:}

H1: Debt contracts have a relationship with capital structure adjustment speed.

The results of the model are presented in Table 5.

Table 5: Summary of the results to investigate the first hypothesis

\begin{tabular}{|c|c|c|c|c|}
\hline \multicolumn{5}{|c|}{$\Delta \mathrm{LEV}_{\mathrm{it}+1}=\beta_{0}+\beta_{1} \mathrm{LEVDEV}_{\mathrm{it}}+\beta_{2}$ COVDUMMY $_{\mathrm{it}}+\beta_{2} \mathrm{LEVDEV} * \mathrm{COVDUMMY}_{\mathrm{it}}+\varepsilon_{\mathrm{it}}$} \\
\hline Variable & Coefficient & $\begin{array}{l}\text { Standard } \\
\text { Deviation }\end{array}$ & t statistics & $\begin{array}{r}\text { Sig. level of T } \\
\text { statistics }\end{array}$ \\
\hline Intercept & 0.621 & 0.012 & 48.6892 & 0.000 \\
\hline Financial Leverage Difference (LEVDEV) & 0.988 & 0.003 & 26.6991 & 0.000 \\
\hline Debt contracts(COVDUMMY) & 0.002 & 0.007 & 0.3364 & 0.648 \\
\hline $\begin{array}{l}\text { Debt Contracts and Financial Leverage Difference } \\
\text { (LEVDEVCOV) }\end{array}$ & 0.004 & 0.003 & 1.369 & 0.162 \\
\hline F Fisher statistic (significance level) & $\begin{array}{l}43.998 \\
(0.000)\end{array}$ & \multicolumn{2}{|c|}{ Durbin-Watson statistic } & 1.744 \\
\hline Coefficient of determination & 0.541 & \multicolumn{2}{|c|}{$\begin{array}{l}\text { Adjusted coefficient of } \\
\text { determination }\end{array}$} & 0.583 \\
\hline
\end{tabular}

Based on the results that are presented in Table 5, Durbin-Watson statistic is used to investigate the lack of autocorrelation being 1.744, its optimal range being between 1.5 and 2.5 , and the lack of autocorrelation shown between the data. On the one hand, the significance level of fisher statistics (f) in the confidence over $95 \%$ is less than 0.05 and is zero, which shows the significance level of the model to investigate the first model. Also, the adjusted adjustment coefficient is 0.583 , which indicates that 58 percent of the variation of the dependent variable is due to the independent variable. Finally, the effect of independent variables and control on dependent variables is shown by means of $t$ statistics in the confidence level of more than 95 percent. The results show that the significance level of $t$ for independent variables of debt and liquidity contract (LEVDEVCOV) is 0.448 and 0.162 , respectively. These figures indicate that there will be no significant relationship between debt contract and capital structure adjustment speed of companies listed on the Tehran Stock Exchange, for a confidence level of more than 95 percent.

\section{Test results of the second hypothesis:}

H2: Debt contracts constraints have a relationship with capital structure adjustment speed.

The results of the model are presented in Table 6.

Table 6: Summary of the results to investigate the second hypothesis

\begin{tabular}{lrrrr}
\hline & $\triangle$ TLEV $_{\text {it }+1}=\beta_{0}+\beta_{1}$ LEVDEV $_{\text {it }}+\beta_{2}$ COVINST $_{\text {it }}+\beta_{2}$ LEVDEV $^{*}$ COVINST $_{\text {it }}+\varepsilon_{\text {it }}$ & \\
Variable & Coefficient & Standard Deviation & $t$ & sig( \\
\hline Intercept & 0.588 & 0.099 & 6.9987 & 0.000 \\
Financial Leverage Difference & 1.001 & 0.004 & 250.7658 & 0.001 \\
(LEVDEV) & -0.014 & 0.031 & -0.401 & 0.142 \\
Debt contracts(COVDUMMY) & -0.004 & 0.004 & -1.324 & 00.142142 \\
Debt contracts and Financial & & & & \\
Leverage Difference & &
\end{tabular}




\begin{tabular}{|c|c|c|c|}
\hline \multicolumn{4}{|c|}{$\Delta \mathrm{TLEV}_{\mathrm{it}+1}=\beta_{0}+\beta_{1} \mathrm{LEVDEV}_{\mathrm{it}}+\beta_{2}$ COVINST $_{\mathrm{it}}+\beta_{\mathrm{a}} \mathrm{LEVDEV}_{*}$ COVINST $_{\mathrm{it}}+\varepsilon_{\mathrm{it}}$} \\
\hline Variable & Coefficient & Standard Deviation $\quad \mathrm{t}$ & ) $\operatorname{sig}($ \\
\hline (LEVDEVCOV) & & & \\
\hline $\begin{array}{l}\text { F Fisher statistic } \\
\text { (significance level) }\end{array}$ & $11.987(0.000)$ & Durbin-Watson statistic & 1.744 \\
\hline Coefficient of determination & 0.597 & Adjusted coefficient of determination & 0.581 \\
\hline
\end{tabular}

In this model, the tests were carried out to investigate the first hypothesis completely. Durbin-Watson statistic was 1.74 and as a result, we can see a lack of autocorrelation, the significance level of fisher statistic (f) is equal to 0.00000 , that is, in order to examine this significant hypothesis, the adjusted coefficient of determination is 0.581 , which indicates that $58 \%$ of the variation of the dependent variable is due to the independent contractual constraint and, finally, in a confidence level of more than $95 \%$, the significant level of $t$ statistic for the contractual constraint variable is 0.42 , which is more than 0.05, and indicates that the assumption $\mathrm{H} 0$ is accepted and our claim based on the existence of a negative relationship between the constraints of debt contract with the capital structure adjustment speed is rejected.

\section{Test results of the third hypothesis:}

H3: The relationship between debt contract constraint and capital structure adjustment speed is more robust in companies that do not have a good financial position.

The results of the model are presented in Table 7.

Table 7: Summary of the results to investigate the third hypothesis

\begin{tabular}{|c|c|c|c|c|}
\hline \multicolumn{5}{|c|}{$\Delta \mathrm{TLEV}_{\mathrm{it}+1}=\beta_{0}+\beta_{1} \mathrm{LEVDEV}_{\mathrm{it}}+\beta_{2} \mathrm{COVDUMMY}_{\mathrm{it}}+\beta_{2} \mathrm{LEVDEV}_{*} \mathrm{COVDUMMY}_{\mathrm{it}}+\beta_{4} \mathrm{FCF}_{i \mathrm{it}}+\beta_{5} \mathrm{FCF}_{*} \mathrm{LEV}_{\mathrm{it}}+\varepsilon_{\mathrm{it}}$} \\
\hline Variable & coefficients & Standard deviation & $\mathrm{t}$ & ) $\operatorname{sig}($ \\
\hline Intercept & 0.078467 & 0.190253 & 0.412436 & 0.6802 \\
\hline $\begin{array}{l}\text { Difference in financial leverage } \\
\text { )LEVDEV( }\end{array}$ & -0.210981 & 0.025787 & -8.181695 & 0.0000 \\
\hline Debt contract COVDUMMY( & -0.000267 & 0.000222 & -1.201857 & 62299 \\
\hline LEVDEVCOV & 0.481310 & 0.977309 & 0.451620 & 0.2359 \\
\hline )FCF(Free cash flow & -0.000264 & 0.000223 & -1.186558 & 0.000 \\
\hline FCFLEV Leverage and cash flow free & 0.000267 & 0.000223 & -1.197664 & 0.2316 \\
\hline F Fisher statistic significance level)( & $6.241450(0.000)$ & Durbin-Watson stat & & 1.73044 \\
\hline Coefficient of determination & 0.566264 & Adjusted coefficien & ermination & 0.475538 \\
\hline
\end{tabular}

According to Table 7, the Durbin-Watson statistic was 1.73 , which specifies that there is no correlation between variables and the Fisher (f) statistic in the confidence level of more than $95 \%$ was equal to zero, which indicates the model's significance for examining the hypothesis. Also, the adjusted coefficient of determination is 0.47 , which indicates that $47 \%$ of the variation of the dependent variable is due to the independent and moderating variables. At the end, the test of the $t$ statistic was performed in a confidence level of more than $95 \%$ to examine the hypothesis. According to Table 7, the significance level of the t statistic is 0.2316 for the moderator variable of the poor financial situation, and this level for debt contract variable was equal to 0.2299 , that is, above 0.05 . It means that H0 hypothesis is confirmed and our claim with regard to the effect of poor financial condition on the relationship between debt contract constraints and capital structure adjustment speed in the companies listed on the Tehran Stock Exchange that are financially good is rejected.

\section{Test results of the fourth hypothesis:}

H4: The relationship between debt contract constraint and capital structure adjustment speed is more robust in companies that have more powerful financial leverage.

The results of the model are presented in Table 8 .

Table 8: Summary of the results to investigate the fourth hypothesis

\begin{tabular}{|c|c|c|c|c|}
\hline \multicolumn{5}{|c|}{ 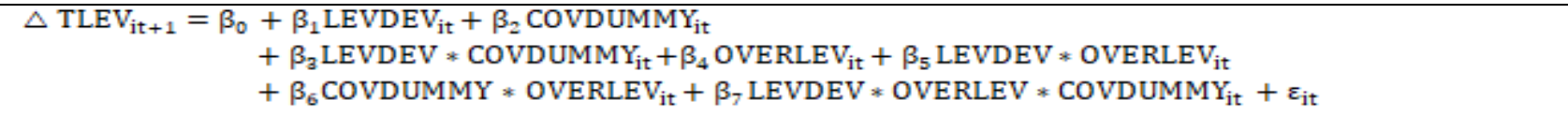 } \\
\hline Variable & Coefficients & $\begin{array}{l}\text { Standard } \\
\text { deviation }\end{array}$ & $\mathrm{T}$ & ) $\operatorname{sig}($ \\
\hline Intercept & 0.5984 & 0.0140 & 45.298 & 0.000 \\
\hline LEVDEV (Difference in financial leverage) & 0.9784 & 0.0049 & 206.898 & 0.000 \\
\hline
\end{tabular}




\begin{tabular}{lrlrr}
\hline COVDUMMY (debt contract) & 0.0081 & 0.0083 & 1.0596 & 0.3012 \\
LEVDEVCOV & 0.0223 & 0.0056 & 3.0245 & 0.004 \\
OVERLEV (too much financial leverage) & 0.0456 & 0.0321 & 2.0156 & 0.0468 \\
LEVDEVOVER & 0.0456 & 0.0321 & 2.0156 & 0.0000 \\
OVERLEVCOV & -0.0345 & 0.0356 & -1.2365 & 0.2384 \\
F Fisher statistic (significance level) & $44.529(0.000)$ & Durbin-Watson statistic & 1.6345 \\
Coefficient of determination & 0.6845 & Adjusted coefficient of determination & 0.6845 \\
\hline
\end{tabular}

Based on the information in Table 8, the Durbin-Watson statistic was 1.63, which postulates that there is no correlation between variables, the significance level of Fisher's statistic is 0.000 , which is less than 0.05 ; therefore, the model is significant for the hypotheses investigation. Also, the adjusted coefficient of determination is 0.47 , which indicates that $47 \%$ of the variation of the dependent variable is due to the independent control variables (moderator). In the end, the test of the $t$ statistic in a confidence level of more than $95 \%$ for too strong financial leverage control variable is 0.0468 and is less than 0.05. It means that $\mathrm{H} 0$ hypothesis is rejected and our claim about the effect of high financial leverage on the relationship between debt contracts, constraints, and capital structure adjustment speed in the companies listed on the Tehran Stock Exchange that are financially good is confirmed.

\section{CONCLUSION}

Although most of the empirical studies have been conducted in line with the capital structure pattern in the U.S. stock exchange and other developed countries, such as England and Japan, the issue of capital structure in the market economy of developed countries has its own special significance. Unfortunately, these issues due to the two reasons mentioned in the coming lines remain ambiguous. First, the developing economies pay less attention to the role of economic entities in the economic development process. Second, almost two decades ago, economic units in most of the developed countries faced serious constraints in choosing the financing opportunities. The dominance of the state economy, the elimination of competition from non-governmental economic units, the lack of market development, and the limited funding sources can be mentioned among these limitations and constraints. Anyway, researches about the optimal structure of capital continue pay attention to the factors affecting the structure of capital from a particular angle. Investigating the factors that are effective on the capital structure helps companies (according to the status quo) choose a combination of financing that has the highest return on equity at a minimum cost. In our country, financing is also faced with fundamental limitations. Choosing the components of capital structure is limited to ordinary shares, loans and, in limited cases, equity bonds. In Iran, up to now, the effect of various factors has been investigated on capital structure, and in most cases, this negative effect or relationship was not present. Based on this fact, and due to the concerns in the market, the current study has been designed to investigate the effect of debt contracts on the capital structure. The results indicate that in the accepted and active companies in the Tehran Stock Exchange from 2011 to 2016, there is no significant relationship between:

1. The debt contract and the capital structure adjustments speed,

2. Debt contract and the capital structure adjustments speed constraints,

3. Debt contract and the capital structure adjustments speed constraints in companies that have a financial problem.

4. However, there is a relationship between debt contract and the capital structure adjustments speed in companies with high leverage.

These findings were inconsistent with the findings of the researchers in other countries, which may be due to the environment condition of Iran or the different perspectives of creditors and their ways of assessing.

\section{SUGGESTIONS FOR FUTURE RESEARCHES}

The following cases can be considered as the suggested topics for future researches:

- The effect of other company related variables should be investigated. For instance, the effect of institutional shareholders, firm size, type of debt, etc., must be examined with the structure of the capital.

- Investigating the effect of political hypotheses on the capital structure.

- Conducting researches on small and medium firms and comparing their results with the results of this study.

\section{DELIMITATIONS OF THE STUDY}

Similar to other studies, the current research too has limitations and the users of the results of this study must pay special attention to them, which are: 
- Five-year research period was tested and the results indicated that although there was no significant research literaturerelated relationship, the explanatory power of the model was suitable among the surveyed companies. Using longer research periods has reduced the number of sample companies or the inflation was effective on the results of the research and this is one of the research limitations.

- The quality of information can also be effective on the results of the research, such that the information on financial reports is used in the same way that companies have provided. Many companies have conditional audit reports that often do not make such adjustment on financial statements. These adjustments can be effective on the results of the research.

- Most of the foreign researches have tested many companies. Due to the imposed constraints in the statistical society because of companies' synchronization, the generalization of results to all economic units should be done cautiously.

- According to the samples that have been gathered from companies accepted in the Tehran Stock Exchange, and sample companies with regard to size, industry, ownership structure, type of products, all active economic units in the country are not necessarily represented; and the generalization of the results of this study should be done cautiously.

- The effects caused by differences in accounting methods in measuring and reporting financial events may affect the results of the research. No adjustment has taken place in this study due to lack of access to information and due to the mentioned differences.

\section{REFERENCES}

Akhtar, S., (2005). "The Determinant of Capital Structure for Australian Multinational and Domestic Corporations", Australian Journal of Management, 3.

Azar, A. \& Mansour M., (1998). "Statistics and its Application in Management", Volume (I), Third Edition, Tehran: The Organization for Researching and Composing University Text books in the Humanities (SAMT).

Brander, A. \& Lewis, R., (1986). "Oligopoly and Financial Structure: The Limited Liability Effect", American Economic Review, 76: 956-970.

De Angelo, H. \& Masulis, R., (1980). "Optimal capital structure under corporate and personal taxation", Journal of Financial Economics, 8(1): 3-29.

Delavar, A., (2004). "Theoretical and Practical Foundations of Research in the Humanities and Social Sciences", Third Edition, Second Revision, Tehran: Roshd Publishing.

Erik D., Shofiqur R. \& Desmond T., (2017). " Debt contracts and the speed of capital structure adjustment", Journal of Corporate Finance, S0929-1199(17)30215-8.

Etemadi, H. \& Montazeri, M., (2013). "Investigating the Factors Affecting the Capital Structure of Listed Companies in Tehran Stock Exchange, Emphasizing on Product market competition", Accounting and Audit, 20 (3): 1-26.

Gojarati, D., (2006). "The Econometric Foundations", Volume 2, Translated by Abrishami, H., Fourth Edition, Tehran: Tehran University Press.

Gorji, A. M. \& Raei, R., (2015). "Explaining the Capital Structure adjustment Speed by means of the Dynamic Model of Optimal Capital Structure with Emphasis on the Product Market Competitiveness Factor", Journal of Financial Knowledge, 8(25).

Guney, Y., Li, L. \& Fairchild, R. (2011). "The relationship between product market competition and capital structure in Chinese listed firms", International Review of Financial Analysis, 2: 41-51.

Hashemi zadeh A. \& Keshavarz mehr, D., (2015). "Investigating the Asymmetry of the Capital Structure Speed: Dynamic Threshold Model", Financial Engineering and Management of Securities, 23: 59-78.

Mohrman, M., (1996). "The use of fixed GAAP provisions in debt contracts", Accounting Horizons, 10 (3): 78-91.

Nabavi, B., (1996). "Introduction to the Method of Research in the Social Sciences", 17th edition, Tehran, Farvardin Publishing.

Nikolaev, V., (2007). "Debt contracts and accounting conservatism", Working paper, University of Chicago.

Pandey, I.M., (2004). "Capital structure, profitability and market structure: Evidence from Malaysia", Asia Pacific Journal of Economics and Business, 8(2): 78-91.

Pour heidari, O., (1995). "Investigating the Factors of the Capital structure adjustment of Accepted Companies in the Tehran Stock Exchange", Master of Science (Management) Thesis, Tehran University. 
Ramsheh M., Soleimani Amiri, Gh., Eskandari, R. \& Ghareh Khani, M., (2017). "Investigating the Capital Structure in Tehran Stock Exchange", Journal of Management and Finance, 5 (18: 35-56.

Rathinasamy, R. S., Krishnaswamy, C. R., \& Mantripragada, K. G., (2000). "Capital structure and product market interaction: An international perspective", Global Business and Finance Review, 5(2): 51-63.

Setayesh, M. \& Jamalian pour, M., (2011). "The Effectiveness of Capital Structure and its Changes on Advancement of Financial Strategies of Companies Listed in Tehran Stock Exchange", Accounting and Auditing, 18(84): 73 -90.

Sinaei, H. (2007). "Investigating the Effect of Internal Factors of Companies on the Formation of Capital Structure of Tehran Stock Exchange Companies", Accounting and Auditing, 14 (48): 63-84.

Sunder, J., Sunder, S.V. \& Zhang, J., (2009). "Borrower Conservatism and Debt Contracting", Working paper, Northwestern University.

Watts, R., (2003). "Conservatism in accounting, Part I: Explanations and implications", Accounting Horizons, 17 (3): $207-221$.

Zhang, J., (2008). "The Contracting Benefits of Accounting Conservatism to Lenders and Borrowers", Journal of Accounting \& Economics, 45: 27-54. 